\title{
Political Connection and Firm's Performance Among Malaysian Firms
}

\author{
Nurul Azlin Azmi ${ }^{1}$, Nor Balkish Zakaria ${ }^{1}$, Fazrul Hanim Abd Sata ${ }^{1} \&$ Zuraidah Mohd Sanusi ${ }^{2}$ \\ ${ }^{1}$ Faculty of Accountancy, UiTM Cawangan Johor, Segamat, Johor, Malaysia \\ ${ }^{2}$ Accounting Research Institute (ARI), Universiti Teknologi MARA, Shah Alam, Selangor, Malaysia \\ Correspondence: Nurul Azlin Azmi, Faculty of Accountancy, UiTM Cawangan Johor, Jalan Universiti Off, 85000 \\ Segamat, Johor, Malaysia. E-mail: nurul516@uitm.edu.my
}

Received: May 12, 2020

Accepted: June 20, 2020

Online Published: June 29, 2020

doi:10.5430/ijfr.v11n3p146

URL: https://doi.org/10.5430/ijfr.v11n3p146

\begin{abstract}
The purpose of this study is to examine the influence of political connections on firms' performance by controlling the effect of board attributes and firms' characteristics. Specifically, it is argued that politically connected firms enjoy a lot of benefits from the government and said to provide greater chances for the firms to increase their wealth. By using 156 public listed firms between the study period of 2012 to 2017, this study maps out political connection based on the $13^{\text {th }}$ Malaysian general election. The results reveal that the appearance of political connections on board gives significant and negative effect on Tobin Q, while significant and positive effect on Return on Asset (ROA) and Return on Equity (ROE). Board independence is also significant to firms' performance. This result implies that political connection is a favour for a better firm's performance and not to firm's value. The findings have an important implication to investors as it suggests that firms with political connection on board perform better.
\end{abstract}

Keywords: political connections, firm performance, corporate governance

\section{Introduction}

Unlike other countries in the world, Malaysian corporate sector is characterised by the existence of politically connected firms as it falls as the second highest politically connected firms (81 politically connected firms) after United Kingdom (Faccio, 2010). Past empirical studies in relation to corporate governance and political connection only focus on the linkages of this relationship. For instance, Johnson \& Mitton (2003) find that politically connected firms suffered a large drop on share prices as compared to non-political connected firms in Malaysia. Current study by Fung, Gul, \& Radhakrishnan (2015) found smaller magnitude of negative stock price reaction after 2008 general election in Malaysia for firms with long period of political connection. Similarly, Chen, Ding, \& Kim (2010) found that share prices of connected firms dropped upon the news of the declining health of Indonesia's President Suharto. However, study by Chung et al.,(2019), based on South Korean listed firms also found negative effect of firms value on politically connected firms especially during political parties regime changes. It is also proved that their traded share price dropped relatively more than their counterparts due to the market's perception that the government would be unable to continue to extend privileges to these firms.

Strong corporate governance mechanism is needed to ensure high quality of financial reporting and better firm performance (Shahzad, 2016). One of the internal governance mechanisms is the board of directors because the director is in the highest position and is the most powerful over the wide range of decision making in the firms. Independent and competent directors may reduce agency cost and able to achieve firm's objective. The appointment of new directors became a crucial part because appointing the right person can bring business prosperity. However, current practice among the firms is appointing someone that has power or influence as a director because firms see this as a resource to them especially to gain benefit from the government.

In line with resources dependency theory, firms prefer to appoint politicians as directors in the firms because directors are seen as resource to the firms. Therefore, firms can enjoy benefit if they appoint politicians as directors because directors can use their influence and can bring resources into the firms. As such, prior studies have found that political connected firms can increase firm performance and value through official government contract (Chung et al., 2019; Sun, Hu, \& Hillman, 2016), preferential access to credit, tax reduction, and market protection (Faccio, 2010). However, political connected firms have negative perspective whereby the quality of accounting information is worse for political connected firms than non-politically connected firms (Chaney, Faccio, \& Parsley, 2011). 
Hashmi, Brahmana, \& Lau, (2018) also found that politically connected firms persist low earnings quality and has high tendency for tax evasion in high corrupt environment (Khlif \& Amara, 2019).

In this study, the relationship between political connection and firms' performance in Malaysia is examined. This is consistent with the extent of literature and current cases of Malaysia that found mixed result on share prices of politically connected firms. The latest issue faced by political connected firms in Malaysia is their traded of share prices of particular firms drop drastically after the $14^{\text {th }}$ general election. Based on MSWG (2018) reports, the traded share prices of Cahya Mata Sarawak Bhd, Gamuda Bhd, George Kent (M) Bhd, Ahmad Zaki Resources Bhd, and MyEG Services Bhd dropped by 40\%, 21\%, 60.1\%, 46.5\%, and 64.1\% respectively after Barisan Nasional (UMNO) loss to Pakatan Harapan (Harapan) during the $14^{\text {th }}$ general election. As a further action, the CEO of Bursa Malaysia Devanesan Evanson (2018) advised for the public listed firms to be natural and there is a need for self-censorship from politician or politically linked person in their business.

Moreover, the political connection did not only affect the firm's performance, but it may also give negative effect to the country. For instance, the recent release of Corruption Perception Index (CPI) rank in 2018 by Transparency International shows Malaysia fell to rank number 62 as compared to rank 55 in the previous year. This ranking dropped drastically and this is considered as the worst position ever to Malaysia for the past ten years due to unresolved issues of 1 Malaysian Development Berhad (1MDB) and Felda Global Ventures (FGV). Further action was taken by advisory board of Malaysian Anti-Corruption Commission (MACC) regarding this issues by urging the Malaysian government to stop appointing politician or politically linked person to be on the board of public companies and government linked companies (GLC) (MSWG, June 2018). Thus, this study intends to investigate whether the presence of political connection is associated with high or low firms' performance by using latest MCCG based on current politic regime in Malaysia.

\section{Literature Review and Hypothesis Development}

Corporate governance reform in Malaysia was started after the Asian financial crisis in 1997/1998 that eroded public confident to invest in Malaysia. Therefore, Malaysian code of corporate governance (MCCG) was introduced in 2000 to regain public confidence. The MCCG highlights the internal and external governance mechanism that should be followed and sustained by the firms. Later, MCCG was revised in 2007, 2012 and 2017 to ensure the code remain competitive in the business environment. As such, MCCG 2017 highlights more on the board composition and independent in which the government requires firms to achieve $30 \%$ female board in the firms and the maximum board tenure set to 9 years. The independence of the board is crucial to ensure the directors can make decision independently without any influence by external factors. This is also supported by Mcfarland (2017), who also claims that directors are no longer independent if they serve longer period of time because they belong to top management and will jeopardise the level of their independence. Therefore, by limiting the tenure of the independent's directors up to nine years, the firms may control the influence of political power in the boardroom.

Political connection in Malaysian businesses was started after the introduction of New Economic Policy (NEP) in 1970 with the main objective to achieve economic equality between ethnics' groups in Malaysia. At this time, the Malays are accounted for approximately $60 \%$ of the population but the business has historically been dominated by the Chinese. Thus, NEP gives bumiputeras the privileges on government contacts, increase access to capital, opportunities to buy assets that are privatized and other subsidiaries (Johnson \& Mitton, 2003). As the consequences, the implementation of NEP had increased state intervention and opened the door to greater political involvement in business sector. Later, New Economic Model (NEM) was introduced in 2010 by the previous Prime Minister with the policy objective to reduce the roles of government in business and to spur private sector investment. Subsequently, in 2011 the Performance Management and Delivery Unit (Pemandu) was introduced with the main objective to reduce the government roles or intervention in business by shifting government's roles from investor to a facilitator. It was expected by Pemandu that there were decreased number of ownerships in the business sector. However, based on Kuala Lumpur Composite Index (KLCI), it was found that the government share has increased from $43.7 \%$ to $47.1 \%$ in which indicating it's contrast with the introduction of NEM. It shows that Pemandu failed to reduce the government or politician intervention in the business sectors.

Due to the increasing political involvement in the business and unique corporate environment on ethnicity lines in Malaysia, there is a need to examine the effect of political connection to firm's performance as prior study had found strong evidence that political connection has influence in the capital market (Faccio, 2006; Johnson \& Mitton, 2003). Besides that, the agency cost tend to be high in politically-connected firm (Shleifer \& Vishny, 1994) because the politician tend to influence the decision making of the firms and to control the manager for the advancement of their political interest. Political connection tends to divert the managers from their fundamental objective in maximizing 
shareholder wealth to politician personal interest. Likewise, firms connected to the current government or future political parties are able to invest more, earn better operating performance, hold more cash, and enjoy better long-term share performance. On the other hand, the notion of political involvement over firms' decision making is important, especially in relation to corporate governance because a strong corporate governance mechanism can reduce political influences in the firms (Nordberg, 2009). As such, latest MCCG 2017 shift the focus from "comply to apply" to encourage listed firms to put more thought and consideration when adopting and reporting their corporate governance practices. As such the following hypothesis is developed:

H1: Political connections have significant effect to firm's performance.

\section{Research Methodology}

A sample of 156 Malaysian public listed firms from Main market of Bursa Malaysia for six years (2012 to 2017) is utilized. Table 1 represents the sample selection procedures and show the final sample is 936 firm-year observation firms after excluding insufficient data. The time frame of the study specifically represents the window of the $13^{\text {th }}$ general election of Malaysia and it includes the period after the enforcement of the Malaysian Code of Corporate Governance 2012. Data on firms' performance - Tobin Q, ROA, and ROE and other financial data are extracted from Eikon DataStream, while data on political connected firms and corporate governance variables are hand collected from the published annual report from Bursa Malaysia website.

Table 1. Sample selection procedures

\begin{tabular}{lcc}
\hline & Political connected & Non-political connected \\
\cline { 2 - 3 } Population & 372 & 708 \\
$(-)$ Insufficient data & $(3)$ & $(142)$ \\
\hline Final sample (Firm-year observation) & $\mathbf{3 6 9}$ & $\mathbf{5 6 7}$ \\
\hline
\end{tabular}

\subsection{Measurement Procedures}

Dependent variables. Consistent with prior firms' performance studies, this study robustly tests firm performance by using two different variables which are financial performance (ROA and ROE) that are considered as backward indicator to represent past result, while stock market performance (Tobin Q),considered as forward indicators that reflect the expected future earnings by the market.

Experimental variable. The political connection firms were identified based on the definition by Faccio (2006); Fan, Wong, \& Zhang (2007); Hashmi et al., (2018) that defined politically connected firms as those who hold at least one of its senior management personnel (for instance as the chairman, chief executive officer, executive director, or secretary of the board) or major shareholder with at least 10 percent shareholding in the firms; or is the current or former president, prime minister, government minister, senior government employee or a member of the parliament. As such, the dummy variable 1 for political connected firm and 0 for non-political connection.

Control variable. The choice of control variables is driven by prior studies which have found them to be significant factors in influencing the firms' performance. This study use control variables of corporate governance variable such as, board size (BSIZE) is measured by total number of directors in the firms; Board Expert (BEXPERT) is measured by total number of directors who have accounting or finance expertise and professional qualification; Board independent (BIND) is measured by total number of independent directors.

This study also controls firm characteristic for instance, Firm size (SIZE) measured by Natural log of total assets; Leverage (LEV) measured by total debt to total equity; Type of industries (INDUSTRY) measured by indicator 1 to 8.

\subsection{Estimation Model}

While examining the influence of political connections on firms' performance, it is imperative to consider other factors that can affect the empirical relationship. The study has used several control variables, which include corporate governance indicators and firms' characteristics. This study pooled all the sample firms and developed the following regression model: 
TobinQ

$$
\begin{aligned}
& =\mathrm{B}_{0}+\mathrm{B}_{1} \text { POLCON }+\mathrm{B}_{2} \text { BSIZE }+\mathrm{B}_{3} \text { BEXPERT }+\mathrm{B}_{4} \text { BIND }+\mathrm{B}_{5} \text { SIZE }+\mathrm{B}_{6} \text { LEV }+\mathrm{B}_{7} \text { INDUSTRY } \\
& +\varepsilon
\end{aligned}
$$

ROA

$$
\begin{aligned}
& =\mathrm{B}_{0}+\mathrm{B}_{1} \text { POLCON }+\mathrm{B}_{2} \text { BSIZE }+\mathrm{B}_{3} \text { BEXPERT }+\mathrm{B}_{4} \text { BIND }+\mathrm{B}_{5} \mathrm{SIZE}+\mathrm{B}_{6} \mathrm{LEV}+\mathrm{B}_{7} \text { INDUSTRY } \\
& +\varepsilon
\end{aligned}
$$

ROE

$$
\begin{aligned}
& =\mathrm{B}_{0}+\mathrm{B}_{1} \text { POLCON }+\mathrm{B}_{2} \text { BSIZE }+\mathrm{B}_{3} \text { BEXPERT }+\mathrm{B}_{4} \text { BIND }+\mathrm{B}_{5} \mathrm{SIZE}+\mathrm{B}_{6} \mathrm{LEV}+\mathrm{B}_{7} \text { INDUSTRY } \\
& +\varepsilon
\end{aligned}
$$

Table 2. Summary of measurement procedures

\begin{tabular}{lll}
\hline \multicolumn{1}{c}{ Variables } & \multicolumn{1}{c}{ Definition } & Sources \\
\hline Dependent Variables & & \\
Tobin Q & (Market value of equity + Total debt)/ Total assets & DataStream \\
ROA & Net profit before tax over total assets & DataStream \\
ROE & Net profit before tax over total equity & DataStream
\end{tabular}

\section{Experimental variable}

POLCON

\section{Control variables}

Corporate governance

BSIZE

BEXPERT

BIND

Firm characteristics

SIZE

LEV

INDUSTRY
Number of directors in the firms

Total number of directors (accounting or finance expertise or professional qualification)

Total number of independent directors

An indicator variable, 1 for political connected firm and 0 otherwise

Annual report

Annual report

Annual report

DataStream

DataStream

Annual report

An indicator 1 for Construction, 2 for Consumer product, 3 for Hotel, 4 for Industrial Product, 5 for Properties, 6 for Plantation; 7 for Trading/Services; 8 for Technology

\section{Result}

\subsection{Descriptive Statistics}

The result of descriptive analysis for the continuous variables and dichotomous variables for the sample as shown in panel A and Panel B indicating the range of minimum and maximum values of the samples. 
Table 3. Descriptive statistics

\begin{tabular}{|c|c|c|c|c|}
\hline \multicolumn{5}{|c|}{ Panel A: Continuous variables } \\
\hline Dependent variable & Mean & Minimum & Maximum & SD \\
\hline Tobin Q & 1.04 & 0.06 & 10.31 & 0.67 \\
\hline ROA & 0.05 & -0.83 & 0.81 & 0.10 \\
\hline ROE & 0.10 & -1.25 & 1.88 & 0.21 \\
\hline \multicolumn{5}{|l|}{ Control Variables } \\
\hline BSIZE & 7.46 & 3 & 14 & 1.85 \\
\hline BEXPERT & 2.21 & 0 & 7 & 1.08 \\
\hline BIND & 3.42 & 1 & 8 & 1.05 \\
\hline SIZE & 5.71 & 4.17 & 7.72 & 0.64 \\
\hline LEV & 0.39 & 0.00 & 5.17 & 0.27 \\
\hline \multicolumn{5}{|c|}{ Panel B: Dichotomous variables } \\
\hline & & \multicolumn{2}{|c|}{ No. of observations } & Percentage \\
\hline Political connection & & \multicolumn{2}{|c|}{369} & 39 \\
\hline Non-political connection & & \multicolumn{2}{|c|}{567} & 61 \\
\hline \multicolumn{5}{|l|}{ Industries } \\
\hline Construction & & \multicolumn{2}{|c|}{90} & 9.62 \\
\hline Consumer product & & \multicolumn{2}{|c|}{168} & 17.95 \\
\hline Hotel & & \multicolumn{2}{|c|}{6} & 0.64 \\
\hline Industrial product & & \multicolumn{2}{|c|}{300} & 32.05 \\
\hline Properties & & \multicolumn{2}{|c|}{102} & 10.90 \\
\hline Plantation & & \multicolumn{2}{|c|}{60} & 6.41 \\
\hline Trading/services & & \multicolumn{2}{|c|}{168} & 17.95 \\
\hline Technology & & \multicolumn{2}{|c|}{42} & 4.48 \\
\hline TOTAL & & \multicolumn{2}{|c|}{369} & 100.00 \\
\hline
\end{tabular}

Table 3 Panel A presents the descriptive statistics for this study. The average Tobin Q for the sample firms is 1.04 with a range between 0.06 to 10.31 . While the average ROA is 0.05 with a range between -0.83 to 0.81 . Then, the average ROE is 0.10 with a range between -1.25 to 1.88 . The control variables of corporate governance show the minimum numbers for BSIZE is 3 and maximum is 14 members in the boardroom. Meanwhile, the minimum number of BEXPERT is 0 and maximum member expert in accounting and finance or have professional background is 7 . This implies that there are a few public listed firms which do not comply with MCCG in which the MCCG 2007 requires the firms to have board members who possess financial literacy. The minimum number of board independent (BIND) is 1 and maximum number is 8 . It shows that sample firms maintain enough independent directors in the boards. The average control variable of firm characteristics such as SIZE and LEV is 5.71, and 0.39 respectively.

Table 3 Panel B presents the descriptive statistics for dichotomous variables. This study shows that $39 \%$ of the sample represents political connected firms. Meanwhile, industrial product $(32.05 \%)$ shows the highest sample distribution of the study and followed by consumer product and trading/services (17.95\%).

\subsection{Univariate Analysis}

Univariate analysis was conducted to test difference of mean test between political and non-political connected firms on firms performance, corporate governance and firms characteristics variables. 
Table 4. Difference of means test

\begin{tabular}{lccc}
\hline & $\begin{array}{c}\text { Political connected } \\
\text { firms }\end{array}$ & $\begin{array}{c}\text { Non-Political } \\
\text { connected firms }\end{array}$ & T-Statistic \\
\hline Dependent variable & & & \\
\hline Tobin Q & 0.99 & 1.05 & -0.049 \\
\hline ROA & 0.06 & 0.05 & $0.02^{* *}$ \\
\hline ROE & 0.11 & 0.09 & $0.03^{*}$ \\
\hline Control Variables & 7.71 & 7.29 & $0.43^{* * *}$ \\
\hline BSIZE & 2.06 & 2.31 & $-0.25^{* * *}$ \\
\hline BEXPERT & 3.66 & 3.27 & $0.39^{* * *}$ \\
\hline BIND & 5.82 & 5.64 & $0.18^{* * *}$ \\
\hline SIZE & 0.40 & 0.38 & 0.02 \\
\hline LEV & & & \\
\hline $\begin{array}{l}\text { Note: Tobin Q is measured by market value of equity plus total debt over total assets. ROA is return on assets. } \\
\text { ROE is return on equity. POLCON is indicator variable 1 for political connected firms, } 0 \text { otherwise. BSIZE is } \\
\text { measured by total number of directors in the firm. BEXPERT is measured by total number of directors } \\
\text { (accounting or finance expertise or professional qualification). BIND is measured by total number of independent } \\
\text { directors. SIZE is natural log of total assets. LEV is total debt to total equity. INDUSTRY represents industries. }\end{array}$ \\
\hline
\end{tabular}

Table 4 represents the difference of means test for political and non-political connected firms. The results indicate that ROA and ROE for political connected firms is higher than non-political connected firms with significant difference at $10 \%$ and 5\% respectively. Corporate governance variable shows that BSIZE, BIND, and BEXPERT for political connection firms are higher than non-political connection firms. This implies that political connected firms maintain good corporate governance rather than non-political connected firms, while firm size (SIZE) of the political connected firms is larger than non-political connected firms. This finding is consistent with prior researcher who suggests that political connections are more prevalent in large firms as compared to small firms (Faccio, 2006).

\subsection{Correlation Analysis}

The correlation matric present the correlation between the all variable in this study. This is to detect if there is any multicollinearity issue existed.

Table 5. Correlation result

\begin{tabular}{|c|c|c|c|c|c|c|c|c|c|c|}
\hline Variables & $\begin{array}{l}Z \\
0 \\
0 \\
0 \\
0 \\
\varrho\end{array}$ & 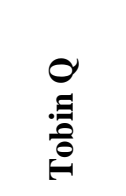 & 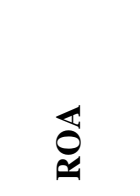 & 덩 & $\frac{\sqrt[T]{N}}{\hat{N}}$ &  & 窝 & $\frac{\sqrt[r]{3}}{\mathfrak{N}}$ & 空 & 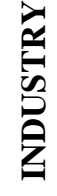 \\
\hline POLCON & 1 & & & & & & & & & \\
\hline Tobin Q & -.041 & 1 & & & & & & & & \\
\hline ROA & $.075^{*}$ & $.267 * *$ & 1 & & & & & & & \\
\hline ROE & $.064 *$ & $.346^{* *}$ & $.631 * *$ & 1 & & & & & & \\
\hline BSIZE & $.119^{* *}$ & $.184 * *$ & $.116^{* *}$ & .049 & 1 & & & & & \\
\hline BEXPERT & $-.109^{* *}$ & -.018 & -.029 & .013 & $.213 * *$ & 1 & & & & \\
\hline BIND & $.184 * *$ & .032 & -.046 & -.009 & $.498 * *$ & $.114 * *$ & 1 & & & \\
\hline SIZE & $.137 * *$ & $.086^{* *}$ & $.110^{* *}$ & $.110 * *$ & $.465 * *$ & $.176^{* *}$ & $.241 * *$ & 1 & & \\
\hline LEV & .028 & $.473 * *$ & $-.141 * *$ & $.143 * *$ & .021 & .012 & $.085 * *$ & .045 & 1 & \\
\hline INDUSTRY & -.017 & .053 & -.038 & .037 & $.096 * *$ & $.207 * *$ & $.140 * *$ & $.283 * *$ & $-.087 * *$ & 1 \\
\hline
\end{tabular}


Note: Tobin $\mathrm{Q}$ is measured by market value of equity plus total debt over total assets. ROA is return on assets. ROE is return on equity. POLCON is indicator variable 1 for political connected firms, 0 otherwise. BSIZE is measured by total number of directors in the firm. BEXPERT is measured by total number of directors (accounting or finance expertise or professional qualification). BIND is measured by total number of independent directors. SIZE is natural $\log$ of total assets. LEV is total debt to total equity. INDUSTRY is represents industries.

Table 5 presents correlation result of this study. It shows that a significant and positive association of POLCON to firms' performance are only found in ROA and ROE. This suggests that political connection influences firms' profit maximization. In addition, the results also suggest that BSIZE, BIND, and SIZE tend to increase with political connection (POLCON). These results are consistent with prior researcher who suggests that political connections are more prevalent in large firms as compared to small firms (Faccio, 2006). However, BEXPERT shows negative association with POLCON and this implies that the greater competency among board members will reduce political power in the firms.

Meanwhile, common financial indicators of SIZE and LEV are the key determinant of firm's well-being and are significant on Tobin Q, ROA, and ROE. The overall result shows that the correlations between all independent variables are less than 0.80 and no multicollinearity issues were suspected (Hair, Black, Babin, \& Anderson, 2010). However, Variance Inflation Factor (VIF) test is discussed in the next subsection.

\subsection{Regression Analysis}

The regression analysis on firm performance proxied by Tobin Q, ROA and ROE as shown in Table 6.

Table 6. Regression result

\begin{tabular}{lrrrrrr}
\hline Variables & \multicolumn{2}{c}{ Model 1 } & \multicolumn{2}{c}{ Model 2 } & \multicolumn{2}{c}{ Model 3 } \\
\hline INTERCEPT & Coefficient & T-Statistic & Coefficient & T-Statistic & Coefficient & T-Statistic \\
POLCON & 0.393 & $2.28^{* *}$ & -0.018 & -.586 & -0.112 & $-1.777^{*}$ \\
BSIZE & -0.092 & $-2.321^{* *}$ & 0.014 & $2.016^{* *}$ & 0.025 & $1.737^{*}$ \\
BEXPERT & 0.099 & $7.639^{* * *}$ & 0.008 & $3.551^{* * *}$ & 0.004 & 0.786 \\
BIND & -0.058 & $-3.147^{* * *}$ & -0.004 & -1.182 & -0.001 & -0.111 \\
SIZE & -0.083 & $-3.957^{* * *}$ & -0.012 & $-3.406^{* * *}$ & -0.015 & $-1.959^{* *}$ \\
LEV & -0.044 & -1.260 & 0.008 & $2.529^{* *}$ & 0.030 & $2.341^{* *}$ \\
INDUSTRY & 1.226 & $17.544^{* * *}$ & -0.055 & $-4.501^{* * *}$ & 0.115 & $4.488^{* * *}$ \\
Adjusted R & 0.025 & $3.890^{* * *}$ & -0.002 & $-1.866^{*}$ & 0.002 & 0.962 \\
F-Statistic & $28.1 \%$ & & $5.5 \%$ & & $3.1 \%$ & \\
P-Value & 53.03 & & 8.78 & & 5.228 & \\
N & $(0.0000)^{* * *}$ & & $(0.0000)^{* * *}$ & & $(0.0000)^{* * *}$ &
\end{tabular}

Note:***,** and $*$ indicate statistical significant at the level $1 \%, 5 \%$, and $10 \%$ (2-Tailed)

Note: Tobin $\mathrm{Q}$ is measured by market value of equity plus total debt over total assets. ROA is return on assets. ROE is return on equity. POLCON is indicator variable 1 for political connected firms, 0 otherwise. BSIZE is measured by total number of directors in the firm. BEXPERT is measured by total number of directors (accounting or finance expertise or professional qualification). BIND is measured by total number of independent directors. SIZE is natural $\log$ of total assets. LEV is total debt to total equity. INDUSTRY represents industries.

Table 6 presents the regression result for this study and the F-statistics for all models shows significant at $1 \%$ level indicating the validity of the model estimation. The results show the coefficient of POLCON is significant and negative on Tobin Q specified in Model 1, while POLCON is positive to ROA in Model 2. This implies that political connection will increase firm financial performance and at the same time can decrease the stock market performance. This can be explained by Efficient Market Hypothesis (EMH). Under semi strong form efficiency, it is contended that security prices have factored in publicly available market and the price changes to new equilibrium levels are reflections from 
the information. As a result, market is vulnerable to any political influence regardless to any ruling parties. Any shock or issue pertaining to politics will be penalised by the market.

The corporate governance variables show BIND negative and significant to all three models -Tobin Q, ROA, and ROE. BSIZE shows positive and significant relationship on Tobin Q and ROA. BEXPERT is only significant and negative on Tobin Q. Financial performance control variables show firms size (SIZE) have positive and significant relationship to financial performance - ROA and ROE. Meanwhile, LEV is significant and has positive relationship on Tobin Q and ROE, and negative relationship on ROA. The Variance inflation factors (VIF) has been observed in all three models, and no multicollinearity (Note 1) issues identified as VIF value were only between 1-3.

\section{Discussion and Conclusion}

Previous researchers that examine the relationship between political connection and firms' performance provide conflicting results. In this study, we examine the association between political connection and firms' performance in Malaysia based on the $13^{\text {th }}$ general election. In addition, we also predict whether political connection has significant effect to the firms' performance. Our findings which are based on 936 firm-year observations suggest that political connection is positive and significant to firms' financial performance - ROA; while it is negative and significant to stock market performance - Tobin Q. Despite improving firms' financial performance, the market is still in favour of any possible political intervention on board. This result is consistent with the Malaysian recent cases where the traded share price of the politically connected firms dropped drastically after the $14^{\text {th }}$ general election. Furthermore, this result is also consistent with prior study that also found share price of politically connected firms dropped than non-political connected firms (Fung et al., 2015; Johnson \& Mitton, 2003); and dropped during political parties regime changes (Chung et al.,2019). Similarly, Chen, Ding, \& Kim (2010) also found that share prices of political connected firms dropped upon the news of Indonesia's President Suharto's declining health.

The control variables of corporate governance, BIND shows significant but negative relationship with firms' performance. This imply that higher number of independent directors in the firms will result to poor performance. This is due to the issue of board tenure among the independent directors. Corporate governance monitoring 2019 documented that 785 independent directors in Malaysia served more than 9 years, with the longest tenure of 40 years. Supported by Mcfarland (2017), who claims that directors are no longer independent if they serve longer period of time because they belong to top management and will jeopardise the level of their independence. Due to this issue, the independent directors are unable to play their duties effectively to control the political power in the firms. Thus, having too many independent directors on board does not really help to boost firms' performance.

The present study has several limitations that should be noted hence providing opportunities for further research. Firstly, the definition of politically connected firms is based on Faccio (2006). Future research should try to categorise or examine political connection using a different method or measurement such as by classifying direct and indirect politically connected firms because politically linked person also has significance effect to the firms' performance. Secondly, it is significant for the future research to study the issue before and after $14^{\text {th }}$ general election as the political parties in Malaysia had changed for the first time after 60 years.

\section{Acknowledgement}

Authors would like to acknowledge the Universiti Teknologi MARA (UiTM) Cawangan Johor and Acocunting Research Institute (ARI) for its full support in undertaking this research

\section{References}

Chaney, P., Faccio, M., \& Parsley, D. (2011). The quality of accounting information in politically connected firms. Journal of Accounting and Economics, 51(1-2), 58-76.

Chen, C., Ding, Y., \& Kim, C. (2010). High-level politically connected firms, corruption, and analyst forecast accuracy around the world. Journal of International Business Studies, 41(9), 1505-1524. https://doi.org/10.1057/jibs.2010.27

Chung, C. Y., Byun, J. H., \& Young, J. (2019). Corporate political ties and firm value: Comparative analysis in the Korean market. Sustainability (Switzerland), 11(2), 1-25. https://doi.org/10.3390/su11020327

Faccio, M. (2006). Politically connected firms. American Economic Review, 96(1), 369-386.

Faccio, M. (2010). Differences between politically connected and non-connected firms: A cross country analysis. Financial Management, 39(3), 905-927.

Fan, J. P. H., Wong, T. J., \& Zhang, T. (2007). Politically connected CEOs, corporate governance, and Post-IPO 
performance of China's newly partially privatized firms. Journal of Financial Economics, 84(2), 330-357. https://doi.org/10.1016/j.jfineco.2006.03.008

Fung, S. Y. K., Gul, F. A., \& Radhakrishnan, S. (2015). Corporate political connections and the 2008 Malaysian election. Accounting, Organizations and Society, 43, 67-86. https://doi.org/10.1016/j.aos.2015.04.001

Hair, J. F., Black, W. C., Babin, B. J., \& Anderson, R. E. (2010). Multivariate Data Analysis (7th ed.). New York: Pearson/Prentice Hall.

Hashmi, M. A., Brahmana, R. K., \& Lau, E. (2018). Political connections, family firms and earnings quality. Management Research Review, 41(4), 414-432. https://doi.org/10.1108/MRR-05-2017-0136

Johnson, S., \& Mitton, T. (2003). Cronyism and capital controls: Evidence from Malaysia. Journal of Financial Economics, 67(2), 351-382. https://doi.org/10.1016/S0304-405X(02)00255-6

Khlif, H., \& Amara, I. (2019). Political connections, corruption and tax evasion: a cross-country investigation. Journal of Financial Crime, 21(4), 545-554. https://doi.org/10.1108/jfc-01-2018-0004

Mcfarland, J. (2017). Countries set out rules on directors' tenure. The Globe and Mail, 1-7. Retrieved from https://www.theglobeandmail.com/report-on-business/careers/management/board-games-2013/countries-set-out -rules-on-directors-tenure/article15574442/

MSWG. (2018a). Active politicians as directors of listed companies. Minority Shareholder Watch Group, pp. 1-10.

MSWG. (2018b). Reforms will spur the market. Minority Shareholder Watchdog Group.

Nordberg, D. (2009). Politic in corporate governance: How power shapes the board's agenda. Working Papers in Business and Sustainability, (3), 1-23.

Shahzad, A. (2016). Detecting earning management and earning manipulation in BRIC countries: A panel data analysis for post global financial crisis period. International Journal of Accounting Research, 4(1), 1-10. https://doi.org/10.4172/ijar.1000134

Shleifer, A., \& Vishny, R. W. (1994). Politicians and firms. The Quarterly Journal of Economics, 109(4), 995-1025.

Sun, P., Hu, H. W., \& Hillman, A. J. (2016). The dark side of board political capital: Enabling blockholder rent appropriation. Academy of Management Journal, 59(5), 1801-1822. https://doi.org/10.5465/amj.2014.0425

\section{Note}

Note 1. Critical point of VIF is $>10$ (Hair et al., 2010) 